\title{
ARTICLE
}

\section{Palladium(II) complexes with a phosphino-oxime ligand: Synthesis, structure and applications to the catalytic rearrangement and dehydration of aldoximes}

\author{
Lucía Menéndez-Rodríguez, ${ }^{a}$ Eder Tomás-Mendivil, ${ }^{a}$ Javier Francos, ${ }^{b}$ Carmen \\ Nájera, ${ }^{c}$ Pascale Crochet, ${ }^{a_{*} *}$ and Victorio Cadierno ${ }^{a_{*} *}$
}

Treatment of $\left[\mathrm{PdCl}_{2}(\mathrm{COD})\right]$ (COD $=1,5$-cyclooctadiene) with 1 and 2 equivalents of 2(diphenylphosphino)benzaldehyde oxime, in dichloromethane at room temperature, led to the selective formation of $\left[\mathrm{PdCl}_{2}\left\{\kappa^{2}-(P, N)-2-\mathrm{Ph}_{2} \mathrm{PC}_{6} \mathrm{H}_{4} \mathrm{CH}=\mathrm{NOH}\right\}\right](\mathbf{1})$ and $\left[\mathrm{Pd}\left\{\kappa^{2}-(P, N)-2-\right.\right.$ $\left.\left.\mathrm{Ph}_{2} \mathrm{PC}_{6} \mathrm{H}_{4} \mathrm{CH}=\mathrm{NOH}\right\}_{2}\right][\mathrm{Cl}]_{2}(2)$, respectively, which represent the first examples of $\mathrm{Pd}(\mathrm{II})$ complexes containing a phosphino-oxime ligand. These compounds, whose structures were fully confirmed by X-ray diffraction methods, were active in the catalytic rearrangement of aldoximes. In particular, using a 5 mol\% of complex 1, a large variety of aldoximes could be cleanly converted into the corresponding primary amides at $100{ }^{\circ} \mathrm{C}$, employing water as solvent and without the assistance of any cocatalyst. Palladium nanoparticles are the active species in the rearrangement process. In addition, when the same reactions were performed employing acetonitrile as solvent, selective dehydration of the aldoximes to form the respective nitriles was observed. For comparative purposes, the catalytic behaviour of an oxime-derived palladacyclic complex has also been briefly evaluated.

\section{Introduction}

The coordination chemistry of heteroditopic ligands featuring mixed $P, N$-donor sets is an area of considerable current interest. The different steric and electronic properties associated with each donor fragment provide a unique reactivity to their metal complexes, a fact that has been widely exploited in homogeneous catalysis. ${ }^{1}$ Phosphines functionalized with amino, imino, pyridyl, iminophosphorane or oxazoline groups are typical examples of this class of ligands, and their coordination chemistry and catalytic applications have been broadly investigated. ${ }^{1}$ By contrast, bidentate phosphine ligands containing an oxime functionality as the second donor group are uncommon in the literature. Indeed, the first, and only examples, of metal complexes containing a coordinated phosphino-oxime, namely [M(COD) $\left\{\kappa^{2}(P, N)\right.$ $\left.\left.\mathrm{Cy}_{2} \mathrm{PCH}_{2} \mathrm{CH}=\mathrm{NOH}\right\}\right]\left[\mathrm{PF}_{6}\right]$ (A in Fig. 1), have been described very recently by Morris and co-workers. ${ }^{2}$ In addition to complexes $\mathbf{A}$, which showed a modest activity in the catalytic hydrogenation of cyclooctene, the phosphino-aldoximes $\mathbf{B}$ and their oxides $\mathbf{C}$ were also employed by Wan and co-workers as auxiliary ligands in copper-catalyzed arylation reactions of amines $^{3}$ and thiols, ${ }^{4}$ as well as in palladium-catalyzed SuzukiMiyaura cross-coupling processes. ${ }^{5}$ However, no well-defined metal complexes could be isolated in these cases.

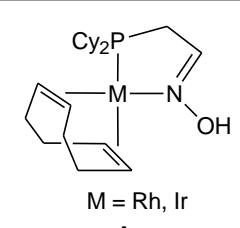

A

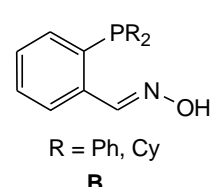

B

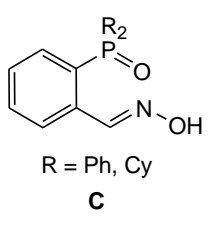

Fig. 1 Structure of phosphino-oxime complexes $\mathbf{A}$ and ligands B-C.

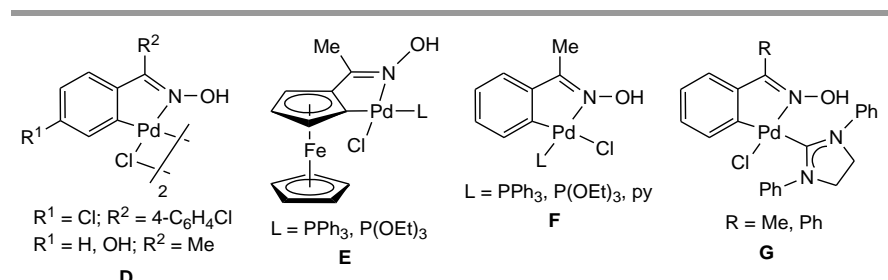

Fig. 2 Structure of the oxime-palladacycles D-G.

The limited interest aroused by this type of $P, N$-donor ligands is quite surprising, since the coordination chemistry of 
oximes has been extensively studied during the last decades. ${ }^{6}$ Relevant to the field of catalysis are, for example, the oximederived palladacycles D-G (Fig. 2), which have proven to be very efficient and versatile pre-catalysts for a wide range of carbon-carbon bond forming reactions in both organic and aqueous media. ${ }^{7}$

On the other hand, owing to the ease of access to the starting materials and the complete atom economy of the process, the metal-catalyzed rearrangement of aldoximes has emerged in recent years as an attractive strategy for the preparation of primary amides (Scheme 1). ${ }^{8,9}$ This transformation, closely related to the well-known Beckmann rearrangement of ketoximes, ${ }^{10}$ involves a dehydration/rehydration sequence via the formation of a discrete nitrile intermediate. Mechanistic studies by Williams and co-workers have also demonstrated that the hydration step can be effected by the own aldoxime substrate, acting as a water surrogate and hydrating the nitrile through the formation of a five-membered metallacyclic intermediate (Scheme 1). ${ }^{11}$

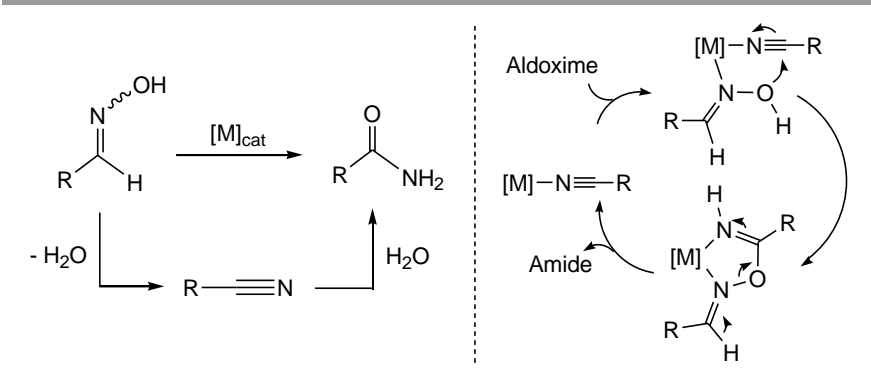

Scheme 1 The catalytic rearrangement of aldoximes and its mechanism.

The first general protocol for this reaction, based on the use of the Wilkinson's catalyst $\left[\mathrm{RhCl}\left(\mathrm{PPh}_{3}\right)_{3}\right]$, was described by Chang and co-workers in 2003. ${ }^{12,13}$ Since then, a huge number of catalytic systems have been developed, with those based on ruthenium complexes being the most common. ${ }^{9}$ Conversely, palladium-based catalysts have so far been poorly studied. Indeed, in addition to $\left[\mathrm{Pd}(\mathrm{acac})_{2}\right]$ early employed by Noltes and co-workers in the rearrangement of acetaldoxime, benzaldoxime and $p$-hydroxybenzaldoxime, ${ }^{13 c, d}$ only the use of $\left[\operatorname{Pd}(\mathrm{en})\left(\mathrm{NO}_{3}\right)_{2}\right] \quad(\mathrm{en}=1,2$-ethylenediamine $)$ has been described. ${ }^{14,15}$ This complex $(10 \mathrm{~mol} \%)$ proved to be active in the rearrangement of a series of non-conjugated aldoximes in water or $\mathrm{MeOH}$ at $60{ }^{\circ} \mathrm{C}$, but resulted completely inoperative with aromatic or $\alpha, \beta$-unsaturated substrates. ${ }^{14}$

With all these precedents in mind, and following with our interest in this catalytic transformation, ${ }^{9,16}$ herein we report the first examples of palladium complexes containing a phosphinooxime ligand, which have enabled us to develop a more general palladium-based protocol for the rearrangement of aldoximes in water. In addition, simply by replacing water by acetonitrile as solvent, an expedient method for the selective conversion of aldoximes into nitriles has been set. For comparative purposes, the catalytic behaviour of an oxime-derived palladacycle $\mathbf{D}$ (Fig. $2 ; \mathrm{R}^{1}=\mathrm{OH}, \mathrm{R}^{2}=\mathrm{Me}$ ) is also briefly discussed.

\section{Results and discussion}

Treatment of the $\mathrm{Pd}(\mathrm{II})$ precursor $\left[\mathrm{PdCl}_{2}(\mathrm{COD})\right](\mathrm{COD}=1,5-$ cyclooctadiene) with a stoichiometric amount of commercially available 2-(diphenylphosphino)benzaldehyde oxime, in dichloromethane at room temperature, led to the selective formation of the mononuclear complex $\left[\mathrm{PdCl}_{2}\left\{\kappa^{2}-(P, N)-2-\right.\right.$ $\left.\left.\mathrm{Ph}_{2} \mathrm{PC}_{6} \mathrm{H}_{4} \mathrm{CH}=\mathrm{NOH}\right\}\right]$ (1) (Scheme 2). This compound, which results from the expected exchange of the labile COD ligand, was isolated as an air-stable yellow solid in $88 \%$ yield. Characterization of $\mathbf{1}$ was straightforward by following its analytical and spectroscopic data (details are given in the Experimental section). Key spectroscopic features are: (i) $\left({ }^{31} \mathrm{P}\left\{{ }^{1} \mathrm{H}\right\} \mathrm{NMR}\right)$ a singlet resonance at $\delta_{\mathrm{P}} 28.0 \mathrm{ppm}$, consistent with the coordination of the $\mathrm{PPh}_{2}$ unit to the metal $(\Delta \delta=42$ ppm with respect to the free ligand). And (ii) $\left({ }^{1} \mathrm{H}\right.$ and ${ }^{13} \mathrm{C}\left\{{ }^{1} \mathrm{H}\right\}$ NMR) the presence of characteristic resonances for the aldoxime $\mathrm{CH}=\mathrm{NOH}$ protons and carbon at $\delta_{\mathrm{H}} 8.28\left(\mathrm{~d},{ }^{4} J_{\mathrm{PH}}=\right.$ $2.7 \mathrm{~Hz}, \mathrm{CH}=\mathrm{N})$ and $11.90(\mathrm{br}, \mathrm{OH}) \mathrm{ppm}$, and $\delta_{\mathrm{C}} 148.9\left(\mathrm{~d},{ }^{3} J_{\mathrm{PC}}\right.$ $=8.8 \mathrm{~Hz}) \mathrm{ppm}$, respectively. In addition, a X-ray diffraction study unequivocally corroborated the postulated structure (details are given in the ESI file).

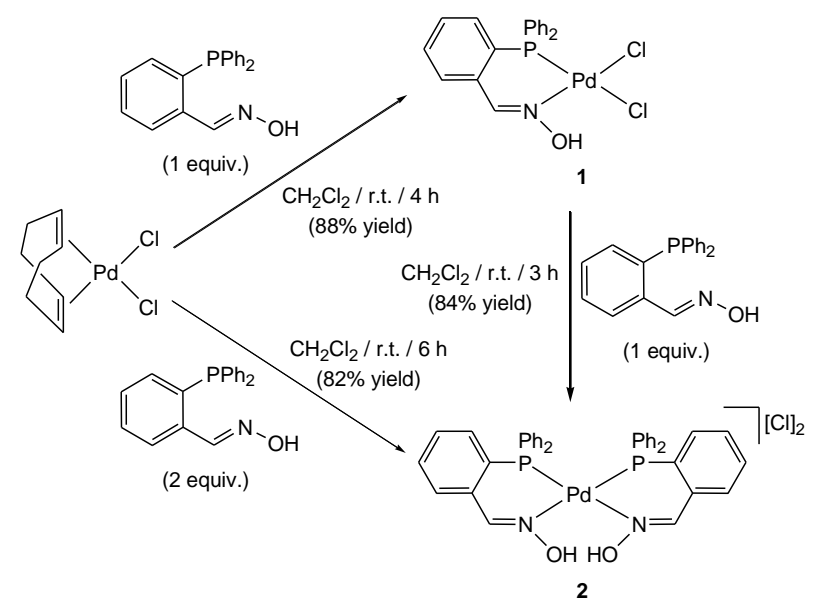

Scheme $\mathbf{2}$ Synthesis of complexes $\mathbf{1}$ and $\mathbf{2}$.

Incorporation of two molecules of the phosphino-oxime ligand in the coordination sphere of palladium could be easily achieved by treatment, at room temperature, of a dichloromethane solution of $\left[\mathrm{PdCl}_{2}(\mathrm{COD})\right]$ with a two-fold excess of 2- $\mathrm{Ph}_{2} \mathrm{PC}_{6} \mathrm{H}_{4} \mathrm{CH}=\mathrm{NOH}$. By this way, the dicationic complex $\left[\mathrm{Pd}\left\{\kappa^{2}-(P, N)-2-\mathrm{Ph}_{2} \mathrm{PC}_{6} \mathrm{H}_{4} \mathrm{CH}=\mathrm{NOH}\right\}_{2}\right][\mathrm{Cl}]_{2}$ (2) was isolated as an air-stable yellow solid in $82 \%$ yield (Scheme 2), and its structure fully confirmed by X-ray diffraction methods (see ESI). Alternatively, this compound could also be obtained in similar yield from the reaction of $\mathbf{1}$ with one equivalent of 2$\mathrm{Ph}_{2} \mathrm{PC}_{6} \mathrm{H}_{4} \mathrm{CH}=\mathrm{NOH}$ (Scheme 2). In complete accord with the structure found in the solid state, the ${ }^{31} \mathrm{P}\left\{{ }^{1} \mathrm{H}\right\}$ NMR spectrum of 2 showed the presence of a singlet resonance at $\delta_{\mathrm{P}} 30.8 \mathrm{ppm}$. However, both the ${ }^{1} \mathrm{H}$ and ${ }^{13} \mathrm{C}\left\{{ }^{1} \mathrm{H}\right\}$ NMR spectra displayed in general quite broad signals (see the Experimental section). This fact, along with the low molar conductivity showed by this complex in acetone solution $\left(\Lambda=95 \Omega \cdot \mathrm{cm}^{2} \cdot \mathrm{mol}^{-1}\right.$; in the lower 
limit for 1:1 electrolytes), suggests a fluxional behaviour, involving probably an equilibrium in solution between $\mathbf{2}$ and the monocationic $\mathbf{2}^{\prime}$ and neutral $\mathbf{2}^{\prime \prime}$ species (Scheme 3). The establishment of such equilibriums is not surprising given the well-known hemilabile properties of metal-coordinated $P, N$ donor ligands. ${ }^{1,17}$

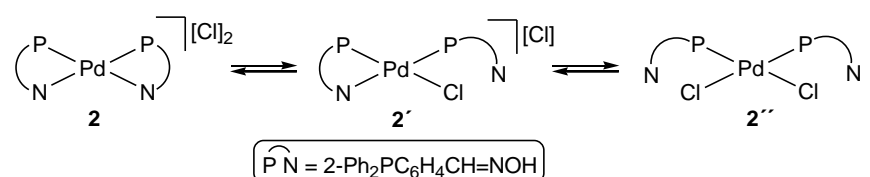

Scheme 3 Proposed behaviour of $\left[\mathrm{Pd}\left\{K^{2}-(P, N)-2-\mathrm{Ph}_{2} \mathrm{PC}_{6} \mathrm{H}_{4} \mathrm{CH}=\mathrm{NOH}\right\}_{2}\right][\mathrm{Cl}]_{2}(2)$ in solution.

Once characterized, the catalytic potential of complexes 1 and $\mathbf{2}$ to promote the rearrangement of aldoximes was evaluated using commercially available $(E)$-benzaldoxime as model substrate. In a typical experiment, the corresponding palladium catalyst $(5 \mathrm{~mol} \%$ ) was added to a $0.33 \mathrm{M}$ aqueous solution of $(E)$-benzaldoxime and the mixture heated in an oil bath at 100 ${ }^{\circ} \mathrm{C}$ for $24 \mathrm{~h}$. To our delight, both complexes were found to be active, providing benzamide in $\geq 98 \%$ GC-yield without adding any cocatalyst (entries 2 and 4 in Table 1). Complete consumption of the starting aldoxime, along with the formation of only very small amounts of benzonitrile $(<2 \%)$ as the only byproduct, was in both cases observed by GC. We would like to recall at this point that complex $\left[\mathrm{Pd}(\mathrm{en})\left(\mathrm{NO}_{3}\right)_{2}\right]$ was unable to rearrange this aromatic aldoxime at $60{ }^{\circ} \mathrm{C},{ }^{14}$ and that $\left[\mathrm{Pd}(\mathrm{acac})_{2}\right]$ required of a higher temperature $\left(180^{\circ} \mathrm{C}\right)$ to achieve a good conversion. ${ }^{13 c, d}$ On the other hand, to determine if differences in activity between complexes $\mathbf{1}$ and $\mathbf{2}$ exist, the same reactions were stopped at a shorter time $(5 \mathrm{~h}$; entries 1 and $3)$. The results obtained pointed out the superior effectiveness of the neutral complex $\left[\mathrm{PdCl}_{2}\left\{\kappa^{2}-(P, N)-2-\right.\right.$ $\left.\left.\mathrm{Ph}_{2} \mathrm{PC}_{6} \mathrm{H}_{4} \mathrm{CH}=\mathrm{NOH}\right\}\right]$ (1), which was able to convert $68 \%$ of the starting aldoxime vs $28 \%$ in the case of 2.

Table 1 Catalytic rearrangement of (E)-benzaldoxime using the palladium(II) complexes $\mathbf{1}$ and $\mathbf{2}^{a}$

\begin{tabular}{|c|c|c|c|c|}
\hline Entry & Catalyst & Time (h) & Conv. $(\%)^{b}$ & Yield $(\%)^{b}$ \\
\hline 1 & 1 & 5 & 68 & 66 \\
\hline 2 & 1 & 24 & $>99$ & 99 \\
\hline 3 & 2 & 5 & 28 & 21 \\
\hline 4 & 2 & 24 & $>99$ & 98 \\
\hline
\end{tabular}

${ }^{a}$ Reactions were performed under Ar atmosphere starting from $1 \mathrm{mmol}$ of (E)-benzaldoxime ( $0.33 \mathrm{M}$ in water). ${ }^{b}$ Determined by GC (uncorrected GC areas). Differences between GC conversions and yields correspond to the intermediate benzonitrile present in the reaction mixture.

The scope of the reaction was next explored using the most active complex $\left[\mathrm{PdCl}_{2}\left\{\kappa^{2}-(P, N)-2-\mathrm{Ph}_{2} \mathrm{PC}_{6} \mathrm{H}_{4} \mathrm{CH}=\mathrm{NOH}\right\}\right]$ (1). First, we focused on a series of substituted benzaldoximes, ${ }^{18}$ performing the catalytic reactions routinely at $100{ }^{\circ} \mathrm{C}$ for $24 \mathrm{~h}$ with a palladium loading of 5 mol \% (entries 2-13 in Table 2). Thus, as observed for the model (E)-benzaldoxime (entry 1), complex 1 was able to generate the corresponding primary amides in high yields $(\geq 79 \%$ by $\mathrm{GC} ; \geq 68 \%$ after chromatographic purification) regardless of the substitution pattern and electronic nature of the starting benzaldoximes. However, we must note that those substrates featuring electrondonating groups showed a higher reactivity (entries 2-6 vs 713). Thus, these benzaldoximes were completely consumed, generating the corresponding benzamides with a very high selectivity (less than $2 \%$ of the nitrile intermediates was present in the crude reaction mixtures; entries 2-6). Conversely, incomplete conversions and a lower selectivity in the amide product were in general observed with benzaldoximes containing electron-withdrawing functionalities (entries 7-13). A similar result was obtained starting from 2-naphthaldoxime (entry 14), from which the corresponding primary amide was formed in a modest $69 \%$ yield. Assuming that the reaction proceeds through the mechanism proposed by Williams (Scheme 1, right), ${ }^{19}$ in which two molecules of the substrate coordinates to the metal, the high steric requirements of this aldoxime may be responsible for the lower reactivity observed.

Table 2 Catalytic rearrangement of aldoximes using the palladium(II) complex $\left[\mathrm{PdCl}_{2}\left\{\kappa^{2}-(P, N)-2-\mathrm{Ph}_{2} \mathrm{PC}_{6} \mathrm{H}_{4} \mathrm{CH}=\mathrm{NOH}\right\}\right](\mathbf{1})^{a}$

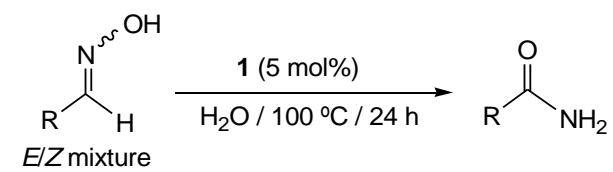

\begin{tabular}{|c|c|c|c|}
\hline Entry & Aldoxime & Conv. $(\%)^{b}$ & Yield $(\%)^{b}$ \\
\hline 1 & $\mathrm{R}=\mathrm{Ph}$ & $>99$ & $99(87)$ \\
\hline 2 & $\mathrm{R}=2-\mathrm{C}_{6} \mathrm{H}_{4} \mathrm{Me}$ & $>99$ & $99(90)$ \\
\hline 3 & $\mathrm{R}=3-\mathrm{C}_{6} \mathrm{H}_{4} \mathrm{Me}$ & $>99$ & $99(86)$ \\
\hline 4 & $\mathrm{R}=4-\mathrm{C}_{6} \mathrm{H}_{4} \mathrm{Me}$ & $>99$ & $99(88)$ \\
\hline 5 & $\mathrm{R}=4-\mathrm{C}_{6} \mathrm{H}_{4} \mathrm{OMe}$ & $>99$ & $98(84)$ \\
\hline 6 & $\mathrm{R}=4-\mathrm{C}_{6} \mathrm{H}_{4} \mathrm{SMe}$ & $>99$ & $98(88)$ \\
\hline 7 & $\mathrm{R}=3-\mathrm{C}_{6} \mathrm{H}_{4} \mathrm{Cl}$ & 97 & $97(85)$ \\
\hline 8 & $\mathrm{R}=4-\mathrm{C}_{6} \mathrm{H}_{4} \mathrm{Cl}$ & 92 & $88(76)$ \\
\hline 9 & $\mathrm{R}=2,6-\mathrm{C}_{6} \mathrm{H}_{3} \mathrm{Cl}_{2}$ & $>99$ & $99(85)$ \\
\hline 10 & $\mathrm{R}=2-\mathrm{Cl}-6-\mathrm{C}_{6} \mathrm{H}_{3} \mathrm{~F}$ & 96 & $93(80)$ \\
\hline 11 & $\mathrm{R}=\mathrm{C}_{6} \mathrm{~F}_{5}$ & $>99$ & $93(82)$ \\
\hline 12 & $\mathrm{R}=2-\mathrm{C}_{6} \mathrm{H}_{4} \mathrm{NO}_{2}$ & 88 & $86(71)$ \\
\hline 13 & $\mathrm{R}=4-\mathrm{C}_{6} \mathrm{H}_{4} \mathrm{NO}_{2}$ & 79 & $79(68)$ \\
\hline 14 & $\mathrm{R}=$ 2-Naphthyl & 76 & $69(58)$ \\
\hline 15 & $\mathrm{R}=n-\mathrm{C}_{5} \mathrm{H}_{11}$ & 98 & $97(85)$ \\
\hline 16 & $\mathrm{R}=n-\mathrm{C}_{6} \mathrm{H}_{13}$ & $>99$ & $98(84)$ \\
\hline 17 & $\mathrm{R}=\mathrm{CH}_{2} \mathrm{CH}_{2} \mathrm{Ph}$ & $>99$ & $99(90)$ \\
\hline 18 & $\mathrm{R}=\mathrm{Cy}$ & 84 & $84(75)$ \\
\hline 19 & $\mathrm{R}=(S)$-Citronellyl & $>99$ & $99(84)$ \\
\hline 20 & $\mathrm{R}=(E)-\mathrm{CH}=\mathrm{CHPh}$ & $>99$ & $99(91)$ \\
\hline 21 & $\mathrm{R}=(E)-\mathrm{CH}=\mathrm{CH}-4-\mathrm{C}_{6} \mathrm{H}_{4} \mathrm{Cl}$ & $>99$ & $99(88)$ \\
\hline
\end{tabular}

${ }^{a}$ Reactions were performed under Ar atmosphere starting from $1 \mathrm{mmol}$ of the corresponding aldoxime ( $0.33 \mathrm{M}$ in water). ${ }^{b}$ Determined by GC (uncorrected GC areas), isolated yields after the work-up are given in brackets. Differences between GC conversions and yields correspond to the intermediate nitrile present in the reaction mixture.

As shown in Table 2, complex $\left[\operatorname{PdCl}_{2}\left\{\kappa^{2}-(P, N)-2-\right.\right.$ $\left.\left.\mathrm{Ph}_{2} \mathrm{PC}_{6} \mathrm{H}_{4} \mathrm{CH}=\mathrm{NOH}\right\}\right]$ (1) was also effective in the rearrangement of a variety of aliphatic (entries 15-20) and $\alpha, \beta$ - 
unsaturated aldoximes (entries 20-21), thus confirming the wide scope of this catalytic transformation. With the exception of the bulky cyclohexylaldoxime (entry 18), conversions above $98 \%$ were in all the cases achieved, allowing the isolation of the corresponding amides in high yields $(\geq 84 \%)$. As in the precedent cases, the presence of only very minor amounts of the intermediate nitriles was observed by GC in the crude reaction mixtures. Furthermore, the chiral centre of $(S)$ citronellaldoxime remained unaffected during the rearrangement reaction (entry 19). ${ }^{20}$

Employing again $(E)$-benzaldoxime as model substrate, we also studied the effect of the solvent in the rearrangement process (see Table 3). To our surprise, under the same experimental conditions, the use of organic solvents instead of water proved highly detrimental since, in most of the cases, the starting aldoxime was recovered mostly unchanged after the 24 $\mathrm{h}$ of heating. Only when the reaction was performed in acetonitrile complete consumption of the substrate was observed (entry 4). However, benzonitrile instead of benzamide was in this case predominantly formed ( $c$. $97 \%$ by GC). We must note at this point that a similar reaction outcome was reported by Tambara and Pantoş employing complex $\left[\mathrm{Pd}(\mathrm{en})\left(\mathrm{NO}_{3}\right)_{2}\right]$ as catalyst. ${ }^{14}$ Their reactions performed in acetonitrile stopped at the aldoxime dehydration step, yielding the corresponding nitrile along with one equivalent of acetamide. Inspection by ${ }^{1} \mathrm{H}$ and ${ }^{13} \mathrm{C}\left\{{ }^{1} \mathrm{H}\right\}$ NMR spectroscopy of the crude reaction mixture revealed that an equimolar amount of acetamide is also generated in our reaction. The $\mathrm{H}_{2} \mathrm{O}$ transfer from the starting aldoxime to the acetonitrile solvent further evidences the operability of the bimolecular mechanism proposed by Williams (Scheme 1, right) with complex 1.

Table 3 Catalytic rearrangement of (E)-benzaldoxime using the palladium(II) complex $\mathbf{1}$ in different solvents. ${ }^{a}$

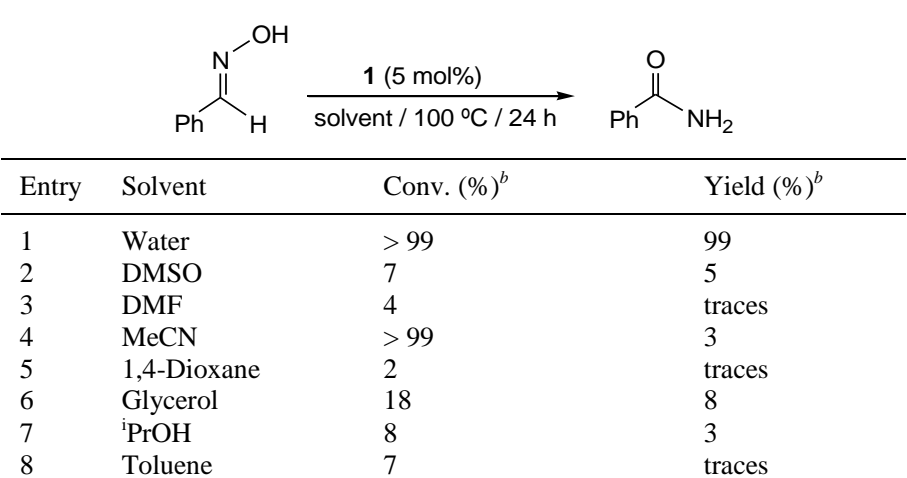

${ }^{a}$ Reactions were performed under Ar atmosphere starting from $1 \mathrm{mmol}$ of (E)-benzaldoxime ( $0.33 \mathrm{M}$ solutions). ${ }^{b}$ Determined by GC (uncorrected GC areas). Differences between GC conversions and yields correspond to the intermediate benzonitrile present in the reaction mixture.

The catalytic dehydration of aldoximes represents a useful and benign method for the synthesis of nitriles, since it avoids the use of toxic cyanide sources commonly employed in the preparation of this relevant class of compounds. Consequently, great efforts have been devoted to this reaction in recent years, and a relatively large number of catalytic systems are now available. ${ }^{21}$ However, as for the rearrangement process, those systems based on palladium are still scarce. Thus, in addition to $\left[\mathrm{Pd}(\mathrm{en})\left(\mathrm{NO}_{3}\right)_{2}\right],{ }^{14}$ only the use of the $\left[\mathrm{Pd}(\mathrm{OAc})_{2}\right] / \mathrm{PPh}_{3} / \mathrm{Cs}_{2} \mathrm{CO}_{3}$ combination has been so far described. ${ }^{22}$ This fact prompted us to study in more detail the usefulness of complex $\left[\mathrm{PdCl}_{2}\left\{\kappa^{2}-\right.\right.$ $\left.\left.(P, N)-2-\mathrm{Ph}_{2} \mathrm{PC}_{6} \mathrm{H}_{4} \mathrm{CH}=\mathrm{NOH}\right\}\right]$ (1) for this dehydration process. To this end, the same aldoximes employed in the rearrangement reactions were subjected to the action of complex $1(5 \mathrm{~mol} \%)$ in acetonitrile. As shown in Table 4, after $24 \mathrm{~h}$ of heating at 100 ${ }^{\circ} \mathrm{C}$, all of them could be smoothly converted into the corresponding nitriles in very high yields $(\geq 93 \%$ by GC; $\geq$ $82 \%$ after chromatographic purification), thus confirming the wide scope of $1 .^{23}$

Table 4 Catalytic dehydration of aldoximes using the palladium(II) complex $\left[\mathrm{PdCl}_{2}\left\{\kappa^{2}-(P, N)-2-\mathrm{Ph}_{2} \mathrm{PC}_{6} \mathrm{H}_{4} \mathrm{CH}=\mathrm{NOH}\right\}\right](\mathbf{1})^{a}$

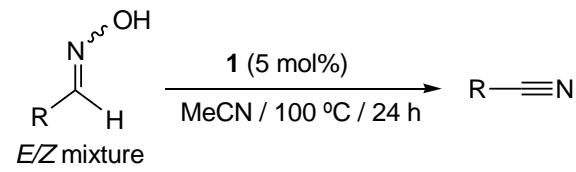

\begin{tabular}{|c|c|c|c|}
\hline Entry & Aldoxime & Conv. $(\%)^{b}$ & Yield $(\%)^{b}$ \\
\hline 1 & $\mathrm{R}=\mathrm{Ph}$ & $>99$ & $97(88)$ \\
\hline 2 & $\mathrm{R}=2-\mathrm{C}_{6} \mathrm{H}_{4} \mathrm{Me}$ & $>99$ & $>99(91)$ \\
\hline 3 & $\mathrm{R}=3-\mathrm{C}_{6} \mathrm{H}_{4} \mathrm{Me}$ & $>99$ & $>99(90)$ \\
\hline 4 & $\mathrm{R}=4-\mathrm{C}_{6} \mathrm{H}_{4} \mathrm{Me}$ & $>99$ & $>99(89)$ \\
\hline 5 & $\mathrm{R}=4-\mathrm{C}_{6} \mathrm{H}_{4} \mathrm{OMe}$ & $>99$ & $99(90)$ \\
\hline 6 & $\mathrm{R}=4-\mathrm{C}_{6} \mathrm{H}_{4} \mathrm{SMe}$ & $>99$ & $99(87)$ \\
\hline 7 & $\mathrm{R}=3-\mathrm{C}_{6} \mathrm{H}_{4} \mathrm{Cl}$ & 95 & $95(80)$ \\
\hline 8 & $\mathrm{R}=4-\mathrm{C}_{6} \mathrm{H}_{4} \mathrm{Cl}$ & $>99$ & $99(90)$ \\
\hline 9 & $\mathrm{R}=2,6-\mathrm{C}_{6} \mathrm{H}_{3} \mathrm{Cl}_{2}$ & $>99$ & $>99(92)$ \\
\hline 10 & $\mathrm{R}=2-\mathrm{Cl}-6-\mathrm{C}_{6} \mathrm{H}_{3} \mathrm{~F}$ & $>99$ & $>99(91)$ \\
\hline 11 & $\mathrm{R}=\mathrm{C}_{6} \mathrm{~F}_{5}$ & 93 & $93(82)$ \\
\hline 12 & $\mathrm{R}=2-\mathrm{C}_{6} \mathrm{H}_{4} \mathrm{NO}_{2}$ & $>99$ & $99(86)$ \\
\hline 13 & $\mathrm{R}=4-\mathrm{C}_{6} \mathrm{H}_{4} \mathrm{NO}_{2}$ & 99 & $99(84)$ \\
\hline 14 & $\mathrm{R}=$ 2-Naphthyl & $>99$ & $>99(89)$ \\
\hline 15 & $\mathrm{R}=n-\mathrm{C}_{5} \mathrm{H}_{11}$ & 99 & $99(89)$ \\
\hline 16 & $\mathrm{R}=n-\mathrm{C}_{6} \mathrm{H}_{13}$ & $>99$ & $>99(90)$ \\
\hline 17 & $\mathrm{R}=\mathrm{CH}_{2} \mathrm{CH}_{2} \mathrm{Ph}$ & 99 & $99(88)$ \\
\hline 18 & $\mathrm{R}=\mathrm{Cy}$ & $>99$ & $>99(92)$ \\
\hline 19 & $\mathrm{R}=(S)$-Citronellyl & $>99$ & $>99(89)$ \\
\hline 20 & $\mathrm{R}=(E)-\mathrm{CH}=\mathrm{CHPh}$ & $>99$ & $>99(90)$ \\
\hline 21 & $\mathrm{R}=(E)-\mathrm{CH}=\mathrm{CH}-4-\mathrm{C}_{6} \mathrm{H}_{4} \mathrm{Cl}$ & $>99$ & $>99(87)$ \\
\hline $22^{c}$ & $\mathrm{R}=3-\mathrm{C}_{6} \mathrm{H}_{4} \mathrm{Cl}$ & 78 & 78 \\
\hline $23^{c}$ & $\mathrm{R}=\mathrm{C}_{6} \mathrm{~F}_{5}$ & 23 & 23 \\
\hline $24^{c}$ & $\mathrm{R}=2$-Naphthyl & 72 & 72 \\
\hline $25^{c}$ & $\mathrm{R}=\mathrm{Cy}$ & 69 & 69 \\
\hline
\end{tabular}

${ }^{a}$ Reactions were performed under Ar atmosphere starting from $1 \mathrm{mmol}$ of the corresponding aldoxime $\left(0.33 \mathrm{M}\right.$ in acetonitrile). ${ }^{b}$ Determined by $\mathrm{GC}$ (uncorrected GC areas), isolated yields after the work-up are given in brackets. Differences between GC conversions and yields correspond to the primary amide present in the reaction mixture. ${ }^{c}$ Reactions performed under refluxing conditions $\left(82^{\circ} \mathrm{C}\right)$ instead of $100^{\circ} \mathrm{C}$.

Remarkably, contrary to the case of the rearrangement reaction, the steric hindrance associated to the bulky 2naphthyl- and cyclohexylaldoxime (entries 14 and 18) now was not detrimental, and the desired 2-naphthalene- and cyclohexene-carbonitrile were generated in almost quantitative yield. In addition to one acetonitrile molecule, coordination of only one molecule of the substrate to the metal is in this case required, which would explain the observed differences 
between both processes. On the other hand, the ${ }^{1} \mathrm{H}$ and ${ }^{13} \mathrm{C}\left\{{ }^{1} \mathrm{H}\right\}$ NMR spectra obtained from the crudes confirmed the formation of an equimolar amount of acetamide with respect to the generated nitrile in all the reactions (trace amounts of the primary amides resulting from the rearrangement of the substrates were also observed in some cases). As shown in entries 22-25, incomplete transformations were observed at a lower temperature (reflux conditions).

Noteworthy, while the reaction profiles of the rearrangement processes in water are characterized by an induction period ( $c a .2 \mathrm{~h}$ in the case of the model $(E)$ benzaldoxime; see Fig. 3), in the dehydration reactions performed in acetonitrile the starting aldoximes are consumed from the beginning (see Fig. 4; only the first 9 hours are shown in both graphics). This fact, along with the gradual appearance of a black solid suspension in the rearrangement reactions carried out in water, raised the question on the real homogeneous or heterogeneous nature of both processes. To shed light on this point, the rearrangement and dehydration reactions of $(E)$-benzaldoxime were performed in the presence of mercury. ${ }^{24}$ Thus, while no major difference in activity was found in the dehydration reaction in acetonitrile, a very poor conversion of $(E)$-benzaldoxime into benzamide was observed after $24 \mathrm{~h}$ in water $(15 \%$ vs $>99 \%$ in the absence of $\mathrm{Hg}(0))$. It appears therefore that different active species, i.e. $\operatorname{Pd}(0)$ nanoparticles and homogeneous $\mathrm{Pd}(\mathrm{II})$ complexes, are operative in water and acetonitrile, respectively. ${ }^{25}$

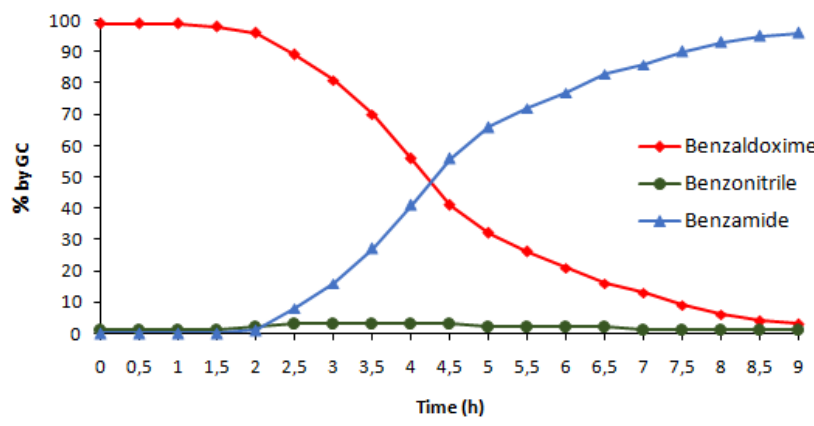

Fig. 3 Product distribution as a function of time for the palladium-catalyzed rearrangement of $(E)$-benzaldoxime in water.

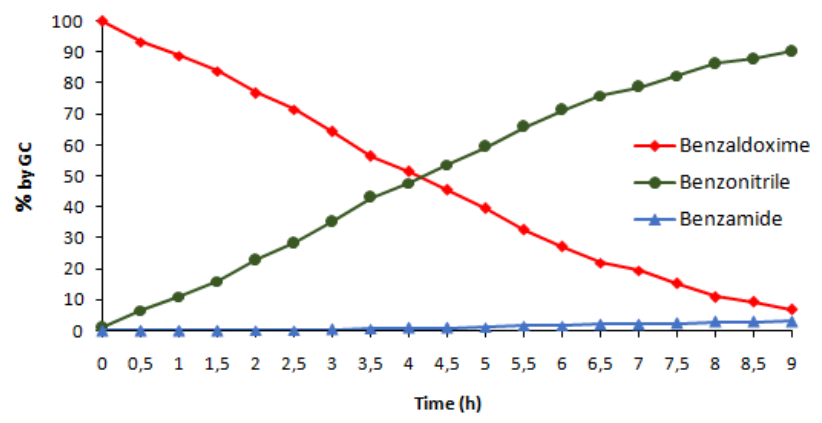

Fig. 4 Product distribution as a function of time for the palladium-catalyzed dehydration of $(E)$-benzaldoxime in acetonitrile.

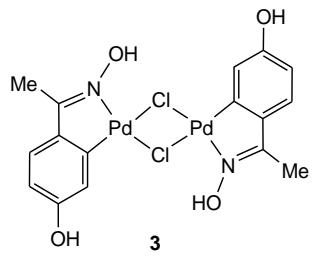

Fig. 5 Structure of the oxime-derived palladacyclic compound 3.

Finally, for comparative purposes, we also studied the catalytic behaviour of the commercially available oximederived palladacycle $\mathbf{3}$ (Fig. 5) in the same catalytic transformations. The results obtained in the rearrangement and dehydration of four selected aldoximes are shown in Tables 5 and 6 , respectively. Interestingly, performing the reactions under identical experimental conditions, we found that, although active and selective in both processes, this palladacyclic compound is less effective than the phosphinoaldoxime complex $\left[\mathrm{PdCl}_{2}\left\{\kappa^{2}-(P, N)-2-\mathrm{Ph}_{2} \mathrm{PC}_{6} \mathrm{H}_{4} \mathrm{CH}=\mathrm{NOH}\right\}\right]$ (1), particularly with aromatic substrates. ${ }^{26}$ This fact together with the limitations found with other previously described palladium catalysts make complex $\mathbf{1}$ an appealing option for future practical applications.

Table 5 Catalytic rearrangement of aldoximes using the oxime-derived palladacyclic complex $\mathbf{3}^{a}$

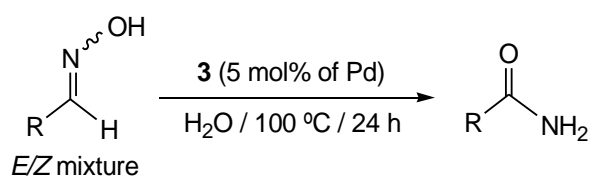

\begin{tabular}{llll}
\hline Entry & Aldoxime & Conv. $(\%)^{b}$ & Yield $(\%)^{b}$ \\
\hline 1 & $\mathrm{R}=\mathrm{Ph}$ & 72 & 69 \\
2 & $\mathrm{R}=4-\mathrm{C}_{6} \mathrm{H}_{4} \mathrm{OMe}$ & 64 & 59 \\
3 & $\mathrm{R}=4-\mathrm{C}_{6} \mathrm{H}_{4} \mathrm{Cl}$ & 78 & 73 \\
4 & $\mathrm{R}=n-\mathrm{C}_{6} \mathrm{H}_{13}$ & 98 & 96
\end{tabular}

${ }^{a}$ Reactions were performed under Ar atmosphere starting from $1 \mathrm{mmol}$ of the corresponding aldoxime $\left(0.33 \mathrm{M}\right.$ in water). ${ }^{b}$ Determined by GC (uncorrected GC areas). Differences between GC conversions and yields correspond to the intermediate nitrile present in the reaction mixture.

Table 6 Catalytic dehydration of aldoximes using the oxime-derived palladacyclic complex $\mathbf{3}^{a}$

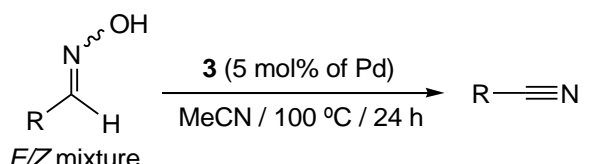

\begin{tabular}{llll}
\hline Entry & Aldoxime & Conv. $(\%)^{b}$ & ${\text { Yield }(\%)^{b}}^{b}$ \\
\hline 1 & $\mathrm{R}=\mathrm{Ph}$ & 74 & 74 \\
2 & $\mathrm{R}=4-\mathrm{C}_{6} \mathrm{H}_{4} \mathrm{OMe}$ & 61 & 61 \\
3 & $\mathrm{R}=4-\mathrm{C}_{6} \mathrm{H}_{4} \mathrm{Cl}$ & 85 & 85 \\
4 & $\mathrm{R}=n-\mathrm{C}_{6} \mathrm{H}_{13}$ & $>99$ & 98
\end{tabular}

${ }^{a}$ Reactions were performed under Ar atmosphere starting from $1 \mathrm{mmol}$ of the corresponding aldoxime ( $0.33 \mathrm{M}$ in acetonitrile). ${ }^{b}$ Determined by GC (uncorrected GC areas). Differences between GC conversions and yields correspond to the primary amide present in the reaction mixture. 


\section{Conclusions}

In this work we have described the first examples of palladium complexes containing a phosphino-oxime ligand, namely $\left[\mathrm{PdCl}_{2}\left\{\kappa^{2}-(P, N)-2-\mathrm{Ph}_{2} \mathrm{PC}_{6} \mathrm{H}_{4} \mathrm{CH}=\mathrm{NOH}\right\}\right](\mathbf{1})$ and $\left[\mathrm{Pd}\left\{\kappa^{2}-(P, N)-\right.\right.$ $\left.\left.2-\mathrm{Ph}_{2} \mathrm{PC}_{6} \mathrm{H}_{4} \mathrm{CH}=\mathrm{NOH}\right\}_{2}\right][\mathrm{Cl}]_{2}$ (2). In addition, we have also demonstrated the utility of these species in catalysis. Thus, using $\mathbf{1}$ and just by selecting the appropriate solvent, highyielding, general and selective protocols for the conversion of aldoximes into primary amides and nitriles could be developed through the rearrangement or dehydration of the substrates, respectively. Remarkably, both processes, which have a high synthetic interest, had been little studied using palladium catalysts, and the previous examples did not show the wide scope featured by complex $\quad\left[\mathrm{PdCl}_{2}\left\{\kappa^{2}-(P, N)-2-\right.\right.$ $\left.\left.\mathrm{Ph}_{2} \mathrm{PC}_{6} \mathrm{H}_{4} \mathrm{CH}=\mathrm{NOH}\right\}\right]$ (1). The results reported herein support further studies on the coordination chemistry and catalytic applications of phosphino-oxime ligands, a field that remains almost unexplored.

\section{Experimental}

\section{General methods}

The manipulations were performed under argon atmosphere using vacuum-line and standard Schlenk or sealed-tube techniques. All reagents were obtained from commercial suppliers and used as received, with the exception of complex $\left[\mathrm{PdCl}_{2}(\mathrm{COD})\right],{ }^{27}$ and most of the aldoximes included in Tables 2 and $4,{ }^{16 a}$ which were prepared following the methods previously reported in the literature. Gas chromatography (GC) measurements were performed on a Hewlett-Packard HP6890 equipment using a Supelco Beta-Dex ${ }^{\mathrm{TM}} 120$ column $(30 \mathrm{~m}$ length; $250 \mu \mathrm{m}$ diameter). Infrared spectra were recorded on a Perkin-Elmer 1720-XFT spectrometer. Conductance measurements were made at room temperature, with $\mathrm{ca} \cdot 10^{-3}$ mol $+\mathrm{dm}^{-3}$ acetone solutions, employing a Jenway PCM3 conductimeter. NMR spectra were recorded on Bruker DPX300 or AV400 instruments. The chemical shift values $(\delta)$ are given in parts per million and are referred to the residual peak of the deuterated solvent employed $\left({ }^{1} \mathrm{H}\right.$ and $\left.{ }^{13} \mathrm{C}\right)$ or to an external $85 \%$ aqueous $\mathrm{H}_{3} \mathrm{PO}_{4}$ solution $\left({ }^{31} \mathrm{P}\right)$. DEPT experiments have been carried out for all the compounds reported. Elemental analyses were provided by the Analytical Service of the Instituto de Investigaciones Químicas (IIQ-CSIC) of Seville.

\section{Synthesis of $\left[\mathrm{PdCl}_{2}\left\{\kappa^{2}-(P, N)-2-\mathrm{Ph}_{2} \mathrm{PC}_{6} \mathrm{H}_{4} \mathrm{CH}=\mathrm{NOH}\right\}\right]$ (1)}

A solution of $\left[\mathrm{PdCl}_{2}(\mathrm{COD})\right](0.200 \mathrm{~g}, 0.700 \mathrm{mmol})$ and 2$\mathrm{Ph}_{2} \mathrm{PC}_{6} \mathrm{H}_{4} \mathrm{CH}=\mathrm{NOH}(0.214 \mathrm{~g}, 0.700 \mathrm{mmol})$ in $30 \mathrm{~mL}$ of dichloromethane was stirred at room temperature for $4 \mathrm{~h}$. The solvent was then removed under reduced pressure to give a yellow solid residue, which was washed with a diethyl ether/hexane mixture $(1: 1 \mathrm{v} / \mathrm{v} ; 3 \times 20 \mathrm{~mL})$ and dried in vacuo. Yield: $0.297 \mathrm{~g}(88 \%)$. IR (KBr): $v=3560$ (br, OH), $1633(\mathrm{~m}$, $\mathrm{C}=\mathrm{N}) \mathrm{cm}^{-1} \cdot{ }^{31} \mathrm{P}\left\{{ }^{1} \mathrm{H}\right\} \mathrm{NMR}\left(\mathrm{CDCl}_{3}\right): \delta=28.0$ (s) ppm. ${ }^{1} \mathrm{H} \mathrm{NMR}$ $\left(\mathrm{CDCl}_{3}\right): \delta=11.90(\mathrm{~s}, 1 \mathrm{H}, \mathrm{OH}), 8.28(\mathrm{~d}, J=2.7 \mathrm{~Hz}, 1 \mathrm{H}$,
$\mathrm{CH}=\mathrm{N}), 7.80-7.43\left(\mathrm{~m}, 13 \mathrm{H}, \mathrm{CH}_{\text {arom }}\right), 7.13(\mathrm{dd}, J=10.8$ and 6.6 $\left.\mathrm{Hz}, 1 \mathrm{H}, \mathrm{CH}_{\text {arom }}\right) \mathrm{ppm} .{ }^{13} \mathrm{C}\left\{{ }^{1} \mathrm{H}\right\} \mathrm{NMR}\left(\mathrm{CDCl}_{3}\right): \delta=148.9(\mathrm{~d}, J=$ $8.8 \mathrm{~Hz}, \mathrm{C}=\mathrm{N}), 135.6\left(\mathrm{~d}, J=9.5 \mathrm{~Hz}, \mathrm{CH}_{\text {arom }}\right), 135.0\left(\mathrm{~s}, \mathrm{CH}_{\text {arom }}\right)$, 134.0 (d, $J=10.6 \mathrm{~Hz}, \mathrm{CH}_{\text {arom }}$ ), 133.5 (s, $\mathrm{CH}_{\text {arom}}$ ), 133.3 (s, $\left.\mathrm{CH}_{\text {arom }}\right), 133.1\left(\mathrm{~d}, J=10.0 \mathrm{~Hz}, \mathrm{C}_{\text {arom }}\right), 132.6(\mathrm{~d}, J=3.2 \mathrm{~Hz}$, $\mathrm{CH}_{\text {arom }}$ ), 129.1 (d, $\left.J=15.8 \mathrm{~Hz}, \mathrm{CH}_{\text {arom }}\right), 126.2(\mathrm{~d}, J=66.5 \mathrm{~Hz}$, $\mathrm{C}_{\text {arom}}$ ), 119.2 (d, $J=49.1 \mathrm{~Hz}, \mathrm{C}_{\text {arom }}$ ) ppm. Elemental analysis calcd. (\%) for $\mathrm{PdC}_{19} \mathrm{H}_{16} \mathrm{Cl}_{2} \mathrm{NOP}$ : C 47.28, H 3.34, N 2.90; found: C 47.12, H 3.39, N 3.01.

\section{Synthesis of $\left[\mathrm{Pd}\left\{\kappa^{2}-(P, N)-2-\mathrm{Ph}_{2} \mathrm{PC}_{6} \mathrm{H}_{4} \mathrm{CH}=\mathrm{NOH}\right\}_{2}\right][\mathrm{Cl}]_{2}(2)$}

A solution of $\left[\mathrm{PdCl}_{2}(\mathrm{COD})\right](0.100 \mathrm{~g}, 0.350 \mathrm{mmol})$ and 2$\mathrm{Ph}_{2} \mathrm{PC}_{6} \mathrm{H}_{4} \mathrm{CH}=\mathrm{NOH}(0.214 \mathrm{~g}, 0.700 \mathrm{mmol})$ in $20 \mathrm{~mL}$ of dichloromethane was stirred at room temperature for $6 \mathrm{~h}$. The solvent was then removed under reduced pressure to give a yellow solid residue, which was washed with diethyl ether ( $3 \mathrm{x}$ $20 \mathrm{~mL})$ and dried in vacuo. Yield: $0.226 \mathrm{~g}(82 \%)$. IR (KBr): $v=$ 3520 (br, OH), $1616(\mathrm{~m}, \mathrm{C}=\mathrm{N}) \mathrm{cm}^{-1} \cdot{ }^{31} \mathrm{P}\left\{{ }^{1} \mathrm{H}\right\} \mathrm{NMR}\left(\mathrm{CD}_{2} \mathrm{Cl}_{2}\right): \delta$ $=30.8$ (s) ppm. ${ }^{1} \mathrm{H}$ NMR $\left(\mathrm{CD}_{2} \mathrm{Cl}_{2}\right): \delta=13.8$ (br, $\left.2 \mathrm{H}, \mathrm{OH}\right), 8.39$ (br, $6 \mathrm{H}, \mathrm{CH}_{\text {arom }}$ ), $8.20(\mathrm{~d}, J=6.3 \mathrm{~Hz}, 2 \mathrm{H}, \mathrm{CH}=\mathrm{N}), 7.65-7.41(\mathrm{~m}$, $\left.18 \mathrm{H}, \mathrm{CH}_{\text {arom }}\right), 6.94\left(\mathrm{~m}, 4 \mathrm{H}, \mathrm{CH}_{\text {arom }}\right)$ ppm. ${ }^{13} \mathrm{C}\left\{{ }^{1} \mathrm{H}\right\}$ NMR $\left(\mathrm{CD}_{2} \mathrm{Cl}_{2}\right): \delta=151.4$ (pseudo t, $J=9.7 \mathrm{~Hz}, \mathrm{C}=\mathrm{N}$ ), 136.4 (br, $\mathrm{C}_{\text {arom }}$ ), 134.4 (br, $\mathrm{CH}_{\text {arom }}$ ), 133.4 (m, $\mathrm{C}_{\text {arom }}$ ), 132.1 (br, $\mathrm{CH}_{\text {arom }}$ ), 131.7 (br, $\mathrm{CH}_{\text {arom}}$ ), 128.9 (br, $\mathrm{CH}_{\text {arom }}$ ), 125.7 (m, $\mathrm{C}_{\text {arom }}$ ) ppm. Elemental analysis calcd. (\%) for $\mathrm{PdC}_{38} \mathrm{H}_{32} \mathrm{Cl}_{2} \mathrm{~N}_{2} \mathrm{O}_{2} \mathrm{P}_{2}$ : C 57.92, H 4.09, N 3.56; found: C 58.01, H 4.03, N 3.62.

General procedure for the catalytic rearrangement of aldoximes with $\left[\mathrm{PdCl}_{2}\left\{\kappa^{2}-(P, N)-2-\mathrm{Ph}_{2} \mathrm{PC}_{6} \mathrm{H}_{4} \mathrm{CH}=\mathrm{NOH}\right\}\right](1)$

The corresponding aldoxime $(1 \mathrm{mmol})$, water $(3 \mathrm{~mL})$, and the palladium(II) complex $1(0.024 \mathrm{~g}, 0.05 \mathrm{mmol})$ were introduced into a Teflon-capped sealed tube, and the reaction mixture stirred at $100{ }^{\circ} \mathrm{C}$ for $24 \mathrm{~h}$. After this time, a sample of ca. $20 \mu \mathrm{L}$ was taken and, after extraction with $\mathrm{CH}_{2} \mathrm{Cl}_{2}(3 \mathrm{~mL})$, analyzed by GC to determine the composition of the reaction mixture. To isolate the amide products, whose identity was assessed by comparison of their NMR spectroscopic data with those reported in the literature, the solvent was eliminated under reduced pressure and the crude reaction mixture purified by column chromatography over silica gel using $\mathrm{CH}_{2} \mathrm{Cl}_{2}$ as eluent.

General procedure for the catalytic dehydration of aldoximes with $\left[\mathrm{PdCl}_{2}\left\{\kappa^{2}-(P, N)-2-\mathrm{Ph}_{2} \mathrm{PC}_{6} \mathrm{H}_{4} \mathrm{CH}=\mathrm{NOH}\right\}\right](1)$

The corresponding aldoxime ( $1 \mathrm{mmol})$, acetonitrile $(3 \mathrm{~mL})$, and the palladium(II) complex $1(0.024 \mathrm{~g}, 0.05 \mathrm{mmol})$ were introduced into a Teflon-capped sealed tube, and the reaction mixture stirred at $100{ }^{\circ} \mathrm{C}$ for $24 \mathrm{~h}$. After this time, a sample of ca. $20 \mu \mathrm{L}$ was taken and, after extraction with $\mathrm{CH}_{2} \mathrm{Cl}_{2}(3 \mathrm{~mL})$, analyzed by GC to determine the composition of the reaction mixture. To isolate the nitrile products, whose identity was assessed by comparison of their NMR spectroscopic data with those reported in the literature, the solvent was eliminated under reduced pressure and the crude reaction mixture purified by column chromatography over silica gel using an ethyl acetate-hexane mixture (40:60 v/v) as eluent. 


\section{Acknowledgements}

This work was supported by the Spanish MINECO (projects CTQ2013-40591-P, CTQ2013-43446-P and CTQ2014-51912REDC) and the Gobierno del Principado de Asturias (project GRUPIN14-006). L.M.-R. and E.T.-M. thank MINECO, MECD and ESF for the award of FPI and FPU fellowships, respectively.

\section{Notes and references}

a Laboratorio de Compuestos Organometálicos y Catálisis (Unidad Asociada al CSIC), Centro de Innovación en Química Avanzada (ORFEO-CINQA), Departamento de Química Orgánica e Inorgánica, Instituto Universitario de Química Organometálica "Enrique Moles", Facultad de Química, Universidad de Oviedo, Julián Clavería 8, E33006 Oviedo, Spain. E-mail: crochetpascale@uniovi.es (P.C.) or vcm@uniovi.es (V.C.); Fax: +(34) 985103446; Tel.: +(34) 985103453.

${ }^{b}$ WestCHEM, University of Strathclyde, Department of Pure and Applied Chemistry, 295 Cathedral Street, Glasgow, G1, 1XL, UK.

c Departamento de Química Orgánica, and Centro de Innovación en Química Avanzada (ORFEO-CINQA), Universidad de Alicante, Apdo. 99, E-03080, Alicante, Spain.

$\dagger$ Electronic Supplementary Information (ESI) available: Details on the X-ray crystal structure determination of compounds $\mathbf{1}$ and 2, and NMR data of the amides and nitriles synthesized in this work. CCDC 1054276 (1) and 1054277 (2). See DOI: 10.1039/b000000x/

1 See, for example: (a) G. R. Newkome, Chem. Rev., 1993, 93, 2067; (b) P. Espinet and K. Soulantica, Coord. Chem. Rev., 1999, 193-195, 499; (c) P. Braunstein and F. Naud, Angew. Chem. Int. Ed., 2001, 40, 680; (d) G. Chelucci, G. Orrù and G. A. Pinna, Tetrahedron, 2003, 59, 9471; (e) P. J. Guiry and C. P. Saunders, Adv. Synth. Catal., 2004, 346, 497; ( $f$ ) P. Braunstein, J. Organomet. Chem., 2004, 689, 3953; (g) I. D. Kostas, Curr. Org. Synth., 2008, 5, 227; (h) M. P. Carroll and P. J. Guiry, Chem. Soc. Rev., 2014, 43, 819; (i) J. GarcíaÁlvarez, S. E. García-Garrido and V. Cadierno, J. Organomet. Chem., 2014, 751, 792.

2 K. Park, P. O. Lagaditis, A. J. Lough and R. H. Morris, Inorg. Chem., 2013, 52, 5448.

3 L. Xu, D. Zhu, F. Wu, R. Wang and B. Wan, Tetrahedron, 2005, 61, 6553. The detailed preparation of the phosphino-adoxime ligands $\mathbf{B}$ is included in this article.

4 D. Zhu, L. Xu, F. Wu and B. Wan, Tetrahedron Lett., 2006, 47, 5781.

5 L. Xu, D. Zhu, F. Wu, R. Wang and B. Wan, J. Mol. Catal. A: Chem., 2005, 237, 210.

6 For selected reviews on this topic, see: (a) A. Chakravorty, Coord. Chem. Rev., 1974, 13, 1; (b) V. Y. Kukushkin, D. Tudela, A. J. L. Pombeiro, Coord. Chem. Rev., 1996, 156, 333; (c) V. Y. Kukushkin, A. J. L. Pombeiro, Coord. Chem. Rev., 1999, 181, 147; (d) A. G. Smith, P. A. Tasker, D. J. White, Coord. Chem. Rev., 2003, 241, 61; (e) P. Chaudhuri, Coord. Chem. Rev., 2003, 243, 143; (f) C. J. Milios, T. C. Stamatatos, S. P. Perlepes, Polyhedron, 2006, 25, 134.

7 Detailed information can be found in the following review articles: (a) D. A. Alonso, L. Botella, C. Nájera and M. C. Pacheco, Synthesis, 2004, 1713; (b) E. Alacid, D. A. Alonso, L. Botella, C. Nájera and M.
C. Pacheco, Chem. Rec., 2006, 6, 117; (c) D. A. Alonso and C. Nájera, Chem. Soc. Rev., 2010, 39, 2891.

8 For general review articles covering metal-catalyzed amide bond forming reactions, see: (a) C. L. Allen and J. M. J. Williams, Chem. Soc. Rev., 2011, 40, 3405; (b) V. R. Pattabiraman and J. W. Bode, Nature, 2011, 480, 471; (c) S. Roy, S. Roy and G. W. Gribble, Tetrahedron, 2012, 68, 9867; (d) R. García-Álvarez, P. Crochet and V. Cadierno, Green Chem., 2013, 15, 46; (e) J. W. Bode, Top. Organomet. Chem., 2013, 44, 13; (f) C. Singh, V. Kumar, U. Sharma, N. Kumar and B. Singh, Curr. Org. Synth., 2013, 10, 241; $(g) \mathrm{N}$. Lukasik and E. Wagner-Wysiecka, Curr. Org. Synth., 2014, 11, 592; (h) P. Crochet and V. Cadierno, Top. Organomet. Chem., 2014, 48, 81.

9 For a specific review on the metal-catalyzed rearrangement of aldoximes, see: P. Crochet and V. Cadierno, Chem. Commun., 2015, 51, 2495.

10 For selected review articles on the Beckmann rearrangement, see: (a) L. G. Donaruma and W. Z. Heldt, Org. React., 1960, 11, 1; (b) R. E. Gawley, Org. React., 1988, 35, 1; (c) R. R. Kumar, K. A. Vanithan and M. Balasubramanian, in Name Reactions for Homologation: Part 2, ed. J. J. Li, John Wiley \& Sons, Hoboken, 2009, pp. 274-292; (d) N. Kaur, P. Sharma and Kishore, J. Chem. Pharm. Res., 2012, 4, 1938.

11 C. L. Allen, R. Lawrence, L. Emmett and J. M. J. Williams, $A d v$. Synth. Catal., 2011, 353, 3262.

12 S. Park, Y.-A. Choi, H. Han, S. H. Yang and S. Chang, Chem. Commun., 2003, 1936.

13 For previous examples of limited applicability, see: (a) W. J. Comstock, Am. Chem. J., 1897, 19, 485; (b) L. Field, P. B. Hughmark, S. H. Shumaker and W. S. Marshall, J. Am. Chem. Soc., 1961, 83, 1983; (c) A. J. Leusink, T. G. Meerbeek and J. G. Noltes, Recl. Trav. Chim. Pays-Bas, 1976, 95, 123; (d) A. J. Leusink, T. G. Meerbeek and J. G. Noltes, Recl. Trav. Chim. Pays-Bas, 1977, 96, 142.

14 K. Tambara and G. D. Pantoş, Org. Biomol. Chem., 2013, 11, 2466.

15 In combination with $\mathrm{Cs}_{2} \mathrm{CO}_{3},\left[\mathrm{Pd}(\mathrm{OAc})_{2}\right]$ was also employed in the one-pot conversion of aldehydes into primary amides in the presence of hydroxylamine hydrochloride, a process involving the rearrangement of aldoxime intermediates: M. A. Ali and T. Punniyamurthy, Adv. Synth. Catal., 2010, 352, 288.

16 (a) R. García-Álvarez, A. E. Díaz-Álvarez, J. Borge, P. Crochet and V. Cadierno, Organometallics, 2012, 31, 6482; (b) R. GarcíaÁlvarez, A. E. Díaz-Álvarez, P. Crochet and V. Cadierno, RSC Adv., 2013, 3, 5889; (c) R. García-Álvarez, M. Zablocka, P. Crochet, C. Duhayon, J.-P. Majoral and V. Cadierno, Green Chem., 2013, 15, 2447; (d) E. Tomás-Mendivil, L. Menéndez-Rodríguez, J. Francos, P. Crochet and V. Cadierno, RSC Adv., 2014, 4, 63466.

17 For a general review on hemilabile ligands, see: C. S. Slone, D. A. Weinberger and C. A. Mirkin, Prog. Inorg. Chem., 1999, 48, 233.

18 Most of the aldoximes employed in this work were synthesized as mixtures of the corresponding $E$ and $Z$ isomers, and, in no case, differences in reactivity between both stereoisomers were observed. The monitoring of the reactions by GC showed that $E$ and $Z$ isomers are consumed at similar rates.

19 Under the same reaction conditions, i.e. in water, at $100{ }^{\circ} \mathrm{C}$, with 5 mol\% of Pd, complexes $\mathbf{1}$ and $\mathbf{2}$ showed a very low activity in the 
catalytic hydration of nitriles ( $c a$. $10 \%$ conversion of benzonitrile to benzamide after $24 \mathrm{~h}$ ). This fact strongly supports the mechanism proposed by Williams and co-workers, in which the initially generated nitrile is hydrated by the own aldoxime substrate (Scheme 1 , right).

20 The specific rotation of the isolated $(S)$-citronellamide was $[\alpha]_{\mathrm{D}}{ }^{20}=$ $9.1(c=1.0 \mathrm{in} \mathrm{EtOH})$. The data available for its enantiomer, i.e. $(R)-$ citronellamide, are $[\alpha]_{\mathrm{D}}{ }^{25}=8.86(c=2.27$ in $\mathrm{MeOH}),[\alpha]_{\mathrm{D}}{ }^{25}=9.2(c=$ 0.3 in $\mathrm{EtOH})$ or $[\alpha]_{\mathrm{D}}{ }^{21}=9.0(c=1.08$ in EtOH $)$. Comparison of these data discards that racemization takes place during the rearrangement reaction. (a) C. G. Overberger and T. Takekoshi, Macromolecules, 1968, 1, 1; (b) R. Lukes, A. Zobacova and J. Plesek, Croat. Chem. Acta, 1957, 29, 201; (c) O. Jeger, V. Prelog, E. Sundt and R. B. Woodward, Helv. Chim. Acta, 1954, 37, 2302.

21 For selected examples, see: (a) S. H. Yang and S. Chang, Org. Lett., 2001, 3, 4209; (b) K. Ishihara, Y. Furuya and H. Yamamoto, Angew. Chem. Int. Ed., 2002, 41, 2983; (c) V. R. Kanetkar, D. D. Zope and Y. V. V. Subramanyam, Ind. J. Chem, Sect. B, 2005, 44, 1317; (d) P. Tamilselvan, Y. B. Basavaraju, E. Sampathkumar and R. Murugesan, Catal. Commun., 2009, 10, 716; (e) N. Jiang and A. J. Ragauskas, Tetrahedron Lett., 2010, 51, 4479; (f) Y.-T. Li, B.-S. Liao, H.-P. Chen and S.-T. Liu, Synthesis, 2011, 2639; (g) X.-Y. Ma, Y. He, T.T. Lu and M. Lu, Tetrahedron, 2013, 69, 2560; (h) Á. Kiss and Z. Hell, Synth. Commun., 2013, 43, 1778; (i) L. Yu, H. Li, X. Zhang, J. Ye, J. Liu, Q. Xu and M. Lautens, Org. Lett., 2014, 16, 1346; (j) W. Jang, S. E. Kim, C. M. Yang, S. Yoon, M. Park, J. Lee, Y. Kim and M. Kim, Catal. Commun., 2015, 60, 120.

22 H. S. Kim, S. H. Kim and J. N. Kim, Tetrahedron Lett., 2009, 50, 1717.

23 The dicationic complex $\left[\mathrm{Pd}\left\{\kappa^{2}-(P, N)-2-\mathrm{Ph}_{2} \mathrm{PC}_{6} \mathrm{H}_{4} \mathrm{CH}=\mathrm{NOH}\right\}_{2}\right][\mathrm{Cl}]_{2}$ (2) also proved active and selective in the dehydration process. Thus, under the same experimental conditions, it was able to generate benzonitrile from $(E)$-benzaldoxime in $95 \%$ GC-yield after $24 \mathrm{~h}$.

24 The $\mathrm{Hg}(0)$-poisoning test is the most direct method to distinguishing homogeneous from heterogeneous catalysis when transition metals able to form an amalgam are employed. See, for example: J. A. Widegren and R. G. Finke, J. Mol. Catal. A: Chem., 2003, 198, 317 and references therein.

25 (a) In the absence of reductant reagents, no fully convincing explanation for the formation of the $\operatorname{Pd}(0)$ nanoparticles during the rearrangement reactions performed in water can be given. However, we must note that the ${ }^{31} \mathrm{P}\left\{{ }^{1} \mathrm{H}\right\}$ NMR spectrum of the crude reaction mixture showed the presence of several singlet resonances in the range $\delta_{\mathrm{P}}=16.5-35.8 \mathrm{ppm}$, some of them attributable to the phosphino-oxides $2-\mathrm{Ph}_{2} \mathrm{P}(=\mathrm{O}) \mathrm{C}_{6} \mathrm{H}_{4} \mathrm{CH}=\mathrm{NOH} \quad\left(\delta_{\mathrm{P}}=29.9\right.$ ppm; literature data $29.7 \mathrm{ppm}), 2-\mathrm{Ph}_{2} \mathrm{P}(=\mathrm{O}) \mathrm{C}_{6} \mathrm{H}_{4} \mathrm{C}(=\mathrm{O}) \mathrm{NH}_{2}\left(\delta_{\mathrm{P}}=34.8 \mathrm{ppm}\right.$; literature data $34.4 \mathrm{ppm})$ and $2-\mathrm{Ph}_{2} \mathrm{P}(=\mathrm{O}) \mathrm{C}_{6} \mathrm{H}_{4} \mathrm{CN}\left(\delta_{\mathrm{P}}=26.0 \mathrm{ppm}\right.$; literature data $26.5 \mathrm{ppm}$ ). It may be that, after decoordination, the own phosphine acts as the reducing agent. Alternatively, a decomposition pathway involving the initial deprotonation of the oxime ligand could also be proposed:

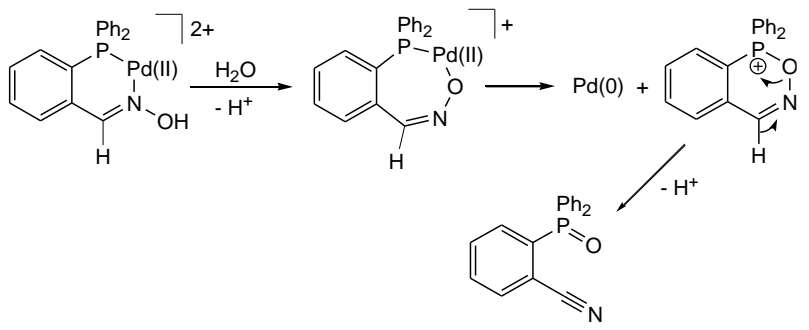

(b) A diminution of the induction period was observed when complex 1 was preheated in water prior to the addition of $(E)$-benzaldoxime. Formation of a black solid suspension was observed; $(c)$ To the best of our knowledge, involvement of Pd nanoparticles in the rearrangement reaction of aldoximes is unprecedented. See ref. 9.

26 As observed for complex 1: (i) the palladacycle $\mathbf{3}$ also decomposes in water generating $\operatorname{Pd}(0)$ nanoparticles, and $(i i)$ an equimolar amount of acetamide is formed in the dehydration processes performed in acetonitrile (no nanoparticles were in this case observed). Oximepalladacycles like $\mathbf{3}$ are known to decompose in aqueous media generating palladium nanoparticles: See ref. $7 c$.

27 D. Drew and J. R. Doyle, Inorg. Synth., 1990, 28, 346. 